\title{
CORE COMPETENCE: A COMPETITIVE BASE FOR ORGANIZATIONAL SUCCESS
}

\author{
Gürhan UYSAL \\ Hacettepe University, Turkey
}

\begin{abstract}
The main object of this study is to investigate the impact of core competence of a firm on organizational success. Core competence is a firm-specific organizational signature that leads to market dominance. It is a signature because represents a firm-specific way of doing business, and emerges from organizational knowledge, expertise, experience, skills, systems, technology, capabilities and resources along with value chain that all differentiate firm from their competitors. Those assets are cornerstones for organizational operations that firm do better than rivals. They also help firm to efficiently produce winning products to increase market share. Core competence achieves this target by leveraging resources and capabilities. It improves the quality of in-house operations with rational resource allocation and usage of distinctive knowledge, expertise, and skills. Therefore, firm beats competition, and dismisses organizational weaknesses, and external threats, and takes advantage of market opportunities. A large number of firms do search for an effective way of managing core competence to respond rapid changes in their environments. Staying in the business depends more on exploiting core competencies in order to reach future priorities and vision of the firm. Thus, a firm's strategies should be based on core competencies to make company successful in the market and to obtain customer value, differentiation, and penetration in to new markets
\end{abstract}

\section{INTRODUCTION}

A mission of strategic management is to provide a firm with competitive advantage by internal resource allocation and capabilities, i.e., is to ensure an organization on competing for future success. The strategic management field is focusing on the role of competencies and resources that accumulate within a firm (Dierickx, Cool, 1989; Barney, 1991; Quelin, Arregle, 2000; Quelin, 2000: 477) because the core competency of a company not only becomes the distinct corporate signature but also provides the company with its competitive advantage (Harvey, Buckley, 1997: 37). Because it is a pool of experience, knowledge, and systems that create and accumulate new strategic assets that constitute a firm's competitive advantage (Duysteers, Hagedoorn, 2000; 76). A firm acquires competitive strength by developing new competencies through organizational transformation with acquisition and integration of knowledge (Carayannis, Alexander, 2002: 626). Such transformation can be observed in HortResearch Company, a New Zealand scientific reserach institute. The core competence strategy process was the major driver of the transformation of HortResearch into a commercially responsive and successful science business (Clark, Scott, 2000: 495). To put another way, Lei et al. (1996), proposed that core competence(s) based on double loop learning produce organizational specialization that is difficult to imitate since competencies have special qualities can provide a sustainable competitive advantage in this way (Gallon, Stillman, 1995: 20).

Core competence is related to resource allocation, capabilities, knowledge, skills, and expertise along with value chain. It needs three elements: skills, resources and processes (Torkkeli, Tuominen, 2002: 282 ), and it is communication, involvement, and a deep commitment to working organizational boundaries (Franklin, 1997: 373). Knowledge resources, innovative creativity and expertise are success factors that create the critical potential of an organization which is termed core competencies (Godbout, 2000: 77). Therefore, a firm's core competence(s) is defined as a set of problem-defining and problem-solving insights that fosters the development of strategic growth alternatives (Lei et al., 1996: 549). In addition, core competencies are the integrated bundles of skills and technologies which are competitively unique and re-deployable (Clark, 2000: 117).

Core competencies are the collective learning in the organization, especially how to coordinate diverse production skills and integrate multiple streams of technologies (Torkkeli, Tuominen, 2002: 273), and are the result of a social learning process in the organization (Godbout, 2000: 78). For example, technological competences are manufacturing plant and equipment, manufacturing know-how, engineering know-how and quality assurance tools, and customer competences are 
knowledge of customer needs and processes, distribution and sales channel, communication channel and company/brand reputation (Danneels, 2002:1103). These knowledge, know-how, and expertise lead to decisions about new product development (Quelin, 2000: 477). New product development is crucial because it describes the extent to which Core competencies are the things that some companies know how to do business uniquely well; for example, some manufacturing corporations have consistently applied core competency and have gained considerable strategic value from the coherency of this approach (Gallon, Stillman, 1995: 21). Constantly focused on the role of competencies and resources, firms' strategic management teams are becoming increasingly interested in discovering an effective way of managing the competencies since, in high-tech sectors, these competencies have a direct impact on the firm's future competitive positioning (Quelin, 2000: 476). ZAP, a high-tech firm, has competence in metal-forming technology, and makes bicycle frame through metal forming, and builds relationship with bicycle manufacturers (Danneels, 2002: 1099). The strategic differences that a firm can maintain with others have been defined upon the extent and levels of resources usage (Banerjee, 2003: 251). When embedded into the social fabric of the firm, competences can provide sources of competitive advantage because they depend on the unique interrelationships between people, routines and technologies that are highly inimitable (Lei et al., 1996: 552).

\section{Core competence: Leveraging Resources and Capabilities}

Core competency thinking is a powerful and widely promoted approach to focus and mobilize an organization's resources; hence, a core competency is defined as an area of specialized expertise that is the result of harmonizing complex streams of technology and work activity (Gallon, Stillman, 1995: 20). Resources are stocks of available factors that are owned or controlled by the firm (Carmeli, Tishler, 2004: 300). Each firm possesses a different profile of tangible and intangible resources and capabilities; hence, differences in profiles among firms account for variations in the firms' competitive position and their performance (Carmeli, Tishler, 2004: 300). By leveraging its resources, a firm increases its strength, and uses them to overcome weaknesses and threats and take advantage of opportunities (Higgins, 1996: 31). Leveraging resources also helps the firm to achieve unreachable goals. The differences among firms in their accumulated resource endowments such as skills, propensity of learning, specialized assets could become important factors to reach organizational success (Lei et al., 1996: 551) because differences and dynamism are key determinants of competitive advantage (Carayannis, Alexander, 2002: 625). Resource-based competencies mean competitive edge. Core competencies are corporation's fundemental strengths, i.e., things that companies do very well (Torkkeli, Tuominen, 2002: 275), and differentiates a firm from its milieu (Banerjee, 2003: 261).

Core competencies should be built upon organizational capabilities, and resources. Gaining superiority in a competitive market depends on a firm's ability to identify, develop, deploy, and preserve particular resources that distinguish it from its rivals (Carmeli, Tishler, 2004: 300). Resources are input based, capabilities are functional or process based, and competencies are cross-functional and based on process integration (Carmeli, Tishler, 2004: 300). Capabilities-based competition means the consistency of firm's product quality, the insight into evolving customer needs, the ability to exploit emerging markets, enter new businesses, or generate new ideas and incorporate them in innovations (Stalk et al., 1992: 57). Capabilities refer to the corporation's ability to exploit its resources (Torkkeli, Tuominen, 2002: 274). Each corporation has various resources, but companies differ in how they leverage them (Torkkeli, Tuominen, 2002: 274). Capabilities make the difference in using resources. Hence, a company determines what skills or capabilities will make them unique in the future (Hamel, Prahalad, 1994: 127). For example, the secret of Wal-Mart's success against its rival, Kmart, which is once an market leader in retailing industry, is a relentless focus on satisfying customer needs, gaining the full benefits of cross-docking, and finally, its human resource system (Stalk et al., 1992: 59). Those are the capabilities of Wal-Mart so as to increase market share.

Wal-Mart's main objective is to improve internal activities and develop organizational process to build capabilities in order to beat rivals. Such firms as GE, Xerox, Motorola, Ikea, and Kodak achieved these goals, and have become well known for their process innovations as well as their product innovations; for example, GE created the work-out (a participative, employee focused, problem-solving retreat) and process mapping (its version of reengineering), both of which have led to significant cost reductions within the corporation (Higgins, 1996: 28). So, top executives are judged on their ability to identify, cultivate, and exploit the core competencies that make growth possible (Prahalad, Hamel, 1990: 79).

The answer to question why competence is a key to organizational success lies on their ability in differentiating a firm from their competitors. To be different and more powerful, company's capabilities and com- 
petencies should be stronger than those of other companies in the industry (Torkkeli, Tuominen, 2002: 275). Capabilities refer to a firm's capacity to deploy resources, usually in combination, using organizational process to affect a desired end (Carmeli, Tishler, 2004: 300). Capabilities are considered core if they differentiate a company strategically (Banerjee, 2003: 251). Thus, resources and capabilities that have high value (i.e., contribute to improving the firm's performance) and rareness (i.e., are possesses by fewer of the firms than the number necessary to create perfect competition dynamics) have the potential to create competitive advantage (Carmeli, Tishler, 2004: 300).

A number of recent contributions highlight the importance of technological competences, technical skills, learning, and knowledge developed within companies for understanding performance differentials (Duysteers, Hagedoorn, 2000: 77). ULTRASONIC firm has customer competence of relations with industrial customers of nondestructive testing ultrasound instruments, good reputation and brand name, and has technological competence of ultrasound diagnostic signal generation and display; therefore, those competencies differentiate the firm from their competitors in producing flaw detector with color monitor, and in developing medical ultrasound diagnostic devices (Danneels, 2002: 1099). Companies develop a unique set of skills for market positioning, combinations of resources, technologies, and personnel that provide competitive differentiation (Harvey, Buckley, 1997: 36). Defining what expertise it possesses enables a firm to more efficiently utilize its resources (McNerney, 1995: 3). Therefore, top management must have a sense of where new opportunities lie, must be able to anticipate changing customer needs, must have invested in building new competencies (Hamel, Prahalad, 1994: 124).

An increasing number of companies now priorities the effective management of competencies through directories, databases, project groups, horizontal structures (Quelin, 2000: 477) since dynamic core competences can be used to reduce uncertainty and to make imitation from other firms difficult (Lei et al, 1996: 549). CHEMAN's dynamic competence is INERT technology, which allows for coating of metal with glass-fused silica technology, and the firm exploits its competence by adding enormous variety of fused silica columns for detection of variety of compounds, and develops ability to coat aluminum with INERT (Danneels, 2002: 1099).

Peter Drucker declares that every organization needs one core competency: innovation that is the core com- petence because it makes competitive advantage by any other strategy possible (Higgins, 1996: 27). This is why; a firm focuses on innovation and internal efficiency to be competitive. For instance, most U.S.based firms can either choose to acquire innovation and make it their core competence, or they can stagnate and watch market share and profits decline (Higgins, 1996: 32). Moreover, internal efficiency depends on skills, expertise, knowledge, values, and structure to efficiently utilize organizational resources so that firm effectively competes in the market. Resources help a firm to create value in the organization, and to mitigate the pressures that industry structure puts on firm profitability (Douglas, Ryman, 2003: 334). The value is the necessary part of improvement of key technological competencies to extend the current product base: Value sharing and the technological co-operation between Saint-Gobain and Scholtes in the market of high-temperature glass used in cooking plates is one such example (Quelin, 2000: 480). Hort Research Company identifies a series of core values that include client focus, environmental ethics, honest and open communication, commitment to scientific excellence, teamwork, and tolerance and respect for diversity (Clark, Scott, 2000: 501).

Core competences can become instituonalized over time and thus become part of the firm's knowledge-creating system (Lei et al., 1996: 552): Technological knowledge, know-how, expertise and technical capabilities support firm's current products. Hence, a company should identify which technologies fit the market and customer needs as well as the organization's core competencies and current strategic plans (Torkkeli, Tuominen, 2002: 271). An example is Canal +, the French pay television company, which has always invested in the technological competencies used in the design of television decoders to remain independent and to control other firms' access to its market (Quelin, 2000: 480). In addition, competences leverage learning and skills to build growth alternatives, and reduce uncertainty (Lei et al., 1996: 564). In a sense, to achieve competitive edge, core competencies should provide potential access to a wide variety of markets, make a significant contribution to the perceived customer benefits of the end products, and should be difficult for competitors to imitate (Prahalad, Hamel, 1990: 84). They should also be (1) unique to the corporation, (2) essential to the development of core products and eventually to end products, and (3) marketable and commercially valuable (Torkkeli, Tuominen, 2002: 275). Hence, successfully developing core competencies depend on organizational learning, knowledge acquisition, experimentation and dynamic organizational routines because those factors lead to accumula- 
tion of universal and tacit knowledge, continuous improvement and firm-specific skills and capabilities (Lei et al., 1996: 555). Tacitness reflects the extent that a competency is intuitive, non-verbalized and yet unarticulated and tacit knowledge is inherently more ambiguous than articulated knowledge (King, Zeithaml, 2001: 77). Tacit knowledge protects a competency from being imitated by competitors. Organizational learning activities include the processes of knowledge-based organizational transformation, and so, the result of improved organizational learning is enhanced strategic flexibility (Carayannis, Alexander, 2002: 626). Moreover, cooperation with the other firms can help an organization to accomplish this goal. Alcatel made cooperation with Sharp in the terminals market to acquire new competencies. Alcatel has knowledge and expertise in the radio technology and in telecommunication networks and Sharp has superiority in LCD screens, memory storage and communications (Quelin, 2000: 480). Through cooperation, technical competencies in Sharp enable Alcatel to gain access into new technological and values that do not possess previously, and vice versa. The right technology can be an essential part of resources needed in the core competence concept (Torkkeli, Tuominen, 2002: 282) because a technology-driven firm creates, renews, and upgrades its latent and enacted capabilities based on its stock of explicit and tacit resources by technological learning (Carayannis, Alexander, 2002: 626).

Building core competencies will enhance using firm's internal resources effectively and taking advantage of capabilities in developing successful products, penetrate emerging markets, and satisfying customer demands. In a sense, the real sources of advantage are to be found in management's ability to consolidate corporate wide technologies and production skills into competencies that empower individual businesses to adapt quickly to changing opportunities (Prahalad, Hamel, 1990: 81). Therefore, to dominate and shape the dynamic market, managers should think of needed skills, technologies, and capabilities that organization must possess. Wright et al. (1998) identified 3 possible core competencies of petrochemical refineries: (1) skilled workforce, (2) efficient production, and (3) new business development. Infrastructure capabilities, for example, concern the internal operations of the company, and technological capabilities provide direct support to the product or service portfolio (Gallon, Stillman, 1995: 22).

David Whitwan, CEO of Whirlpool, believes that the only way to gain lasting competitive advantage is to leverage your capabilities around the world because competitive advantage means having the best tech- nologies and processes for designing, manufacturing, selling, and servicing your products at the lowest possible costs (Higgins, 1996: 31), and (Torkkeli, Tuominen, 2002: 271). Duysters and Hagedorn (2000) say that technological core capabilities generate performance differentials. In addition, technological competencies contribute to firm' competitive strength by determining the renewal of product lines (Quelin, 2000: 476) because technologies can help a company to build competencies around its strategic resources. In order to reach those targets above, companies implement, build, and manage core competence application explained below.

\section{Managing Core Competencies}

Activities, skills and disciplines, which are termed primary capabilities, are the building blocks of core competencies (Gallon, Stillman, 1995: 21). The aptitudes, the skills and motivation of the employees are necessary conditions for developing a core competence because knowledge is carried through human resources to achieve the company's objectives (Godbout, 2000: 78). In a sense, those core competencies must be a capability which the organization can sustain over time (Torkkeli, Tuominen, 2002: 274). In the general hospital industry, the ability to develop capabilities, which are superior to its competitors, is critical for success (Douglas, Ryman, 2003: 335).Accordingly, a core capability is a knowledge-set that distinguishes a firm from its competitors because the knowledge-set has a content embodied in employee knowledge and skills, technical systems, managerial systems and values and norms (Banerjee, 2003: 253). The management of technological capabilities is important because it produces increasing economic returns as they focus more narrowly on knowledge assets and processes that are non-substitutable, rare, and valuable (Carayannis, Alexander, 2002: 626). 3M company, for example, builds their core competence on capabilities in surface coating formulations and continuous coating processes and on know how in technical skills (Gallon, Stillman, 1995: 21). COMP firm in a computer business has skills in peripheral integration and network integration, and produces hardware for portable video editor built on existing technological competence (Danneels, 2002: 1099). These capabilities provide direct support to the product or service portfolio, can provide the basis for significant product superiority, and also give the firm broad strategic value (Gallon, Stillman, 1995: 21). Success in product development and strategic value comes from firm's core competencies that are essential to the development of core products and end products, and that are essential to the implementation of the strategic vision of the corporation (Torkkeli, Tuominen, 2002: 274). 
Core competence development efforts are based on capabilities, resources, organizational learning, $R \& D$ works, technology, and work teams. In addition, the content and form of the core competencies are created through the linkages between the organization's goals, structure and culture (Godbout, 2000: 78). If competencies reside in organizational culture and values, they will be unique and causally ambiguous, and can not to be imitated by rivals because they may be more uncertain and less mobile to the rivals (King, Zeithaml, 2001: 77). The core competency approach in HortResearch Company fitted well with the culture of this company (Clark, Scott, 2000: 506). The operational learning, i.e., learning from experience, contributes to the management of core organizational capabilities, resource allocation, and competitive strategy (Carayannis, Alexander, 2002: 629).

A core competence is acquired through acts of learning on the success and failures of recombination of knowledge resources (Banerjee, 2003: 252). The hierarchy of developing competence is resources, capabilities, competency and finally core competencies (Torkkeli, Tuominen, 2002: 274). A firm firstly determines candidate abilities, knowledge and skills which are valid and applicable in practice. The firm sometimes also creates horizontal workgroups to foster the sharing of experiences and to facilitate the development of new ideas (Quelin, 2000: 476). These abilities, skills etc. should be analyzed before considered as core competences, and pass some qualification criteria (Gallon, Stillman, 1995: 24): Does it harmonize streams of critical technological capabilities? Does it translate into customer-perceived value? Is it difficult to imitate? Are there substantial barriers to competitors? Is it extendable to new markets, i.e., does it provide market mobility? Moreover, dynamic core competences are developed by the integration of systemic organizational learning of knowledge and continuous improvement based on experimentation and the development of firm-specific skills (Lei et al., 1996: 549). Motorola cares about these criteria above, and is the leader in the development of semiconductor solutions for wireless communications systems (Gallon, Stillman, 1995: 24). They recognize the potential competencies in order to develop and exploit, and to leverage their competitive strength in the market. This means appealing to and utilizing potential in the organization as the success factor for an organization's sustainability (Godbout, 2000: 77). R\&D activities can help a firm to find the potential competencies. It renews the firm's portfolio of competencies by identifying the new technologies that are likely to become crucial over time (Quelin, 2000: 481). Therefore, firms and managers ought to show high commitment to core competence program to resolve business challenges (Gallon, Stillman, 1995: 25).

Managers can also set up relationships among universities, competitors, suppliers and clients. Through these linkage strategies, and by establishing durable relationships with external research partners, firms are able to stay abreast of current developments, increase their proximity to competence, and gain access to the resources, knowledge and know-how that they do not possess (Quelin, 2000: 477). These strategic alliances allow a firm to combine resources across organizational boundaries in pursuit of competitive advantage (Douglas, Ryman, 2003: 333). Strategic technology alliances cannot be considered as effective short-term vehicles for the acquisition of core competencies, but instead should be used to complement endogenous capabilities in the long run (Duysters, Hagedoorn, 2000: 84). Because of the increasing complexity of technologies, rapid technological changes, and the increasing costs of $\mathrm{R} \& \mathrm{D}$, firms are no longer able to monitor all the technological developments that are important for their core markets; therefore, strategic technology alliances enable companies to monitor several technological developments, and simultaneously, let them concentrate on a few, most promising, projects internally (Duysters, Hagedoorn, 2000: 84)

Organizations put core competencies into practice to enhance competitiveness in existing product categories, or to focus R\&D and technology investments (Gallon, Stillman, 1995: 20). R\&D is important in core competency practice. Quelin (2000) believes, it develops new key technologies, and implements strategies that lead to an improvement and acquisition of fundemental techonologies. The ability to achieve economies of scope for many crucial products is founded on a common technological knowledge base (Duysters, Hagedoorn, 2000: 84). In the international computer industry, technological knowledge increases the performance of corporate. Thus, technology selection is important to companies. The aim of technology selection is to obtain new know-how, components, and systems which will help the company to make more competitive products and more effective processes (Torkkeli, Tuominen, 2002: 271).

To meet today's R\&D challenges; many of the companies have been attempting to devise new methods for managing technological competence (Quelin, 2000: 476): They compile skills in the organization, managing the breadth of the competence base, or monitoring the competencies that accumulate at the business unit level. For instance, examples of textile competencies 
are a firm's expertise in managing international division or in developing innovative manufacturing processes (King, Zeithaml, 2001: 77). Therefore, to develop a new strategy based on core competence, managers need to understand the purpose and potential of core competencies, and the details of the major components involved (Clark, Scott, 2000: 504).

Building competence requires a large amount and variety of employee participation, and demands rigorous analytical activity (Gallon, Stillman, 1995: 25), and organizational learning (Lei et al., 1996: 553). In addition, core competencies should be developed around strategic business factors because this approach leads to a common understanding of where the key performance gaps were in the business (Clark, Scott, 2000: 507). Core competence-based competitive advantage can be sustainable over time, if the company exploits cumulative learning about the technology effectively (Torkkeli, Tuominen, 2002: 282). Recent conceptual work suggested the importance of organizational learning for core competence development (Lei et al., 1996: 553). Organizational learning translates knowledge into core competences. This is because core capabilities are a function of the firm's ability to organize itself into a knowledge-creating system (Lei et al., 1996: 552). In addition, knowledge creation have often involved the formation of certain types of internal horizontal structures such as project management, virtual R\&D workgroups and the establishment of a co-operative working relationship with the surrounding environment including universities, laboratories, competitors, clients and suppliers (Quelin, 2000: 476).

With knowledge of the organization's existing and potential technical competencies, a firm focuses on evaluating the strategic value of current competencies, and forming an initial view on which potential technical competencies might be strategic (Gallon, Stillman, 1995: 29): A firm also decides where, when, and how to expand the scope of the core competencies. The major problem in managing competencies and $R \& D$ activities is uncertainty. This phenomenon affects firms throughout their activities in mobilizing the basic technological competencies, and internally controlling the interactions between these competencies, and mobilizing all useful competencies (Quelin, 2000: 476).

How can organizations achieve the core competence? They should follow strategic fit and strategic intent approach, and fit their competencies into organizational resources, and internal strengths and weaknesses, and external threats and opportunities. The core competence approach requires ongoing commitment to develop and pursue a long-term strategic intent (Clark, 2000: 125). Full utilization of core competencies and their development into competitive advantage is essential to the realization of the goals established by strategic intent (Torkkeli, Tuominen, 2002: 275). Strategic fit model, i.e. SWOT approach, appears to be more popular in Western firms, and leveraging resources is more popular in Japan (Higgins, 1996: 31): This is why Japanese firms are niche players in the market and give importance to resources, and Western firms are consciousness more about their internal and external environments, and give importance to strategic fit.

State-of-the-art companies adopt core competence approach to go beyond traditional way of doing business. For example, the combination of a specialized technology base and more diversified sales suggests that the internally generated technological core competences can be applied beyond the traditional computer industry (Duysters, Hagedoorn, 2000: 84). A resource or skill-based view focusing on development and application of core competences is offered to supplement the traditional approaches (Lei et al., 1996: 549). On the other hand, Duysters and Hagedoorn (2000) discuss that specialized core knowledge base, the depth of technological competences, technological specialization, and the focus of technological skills appear to generate performance differentials between companies in a high-tech sector, such as the worldwide computer industry. Another example to that is TELECOM Company. TELECOM's technological competence includes RF signal transfer and amplification, and it exploits these competencies by introducing new editions of amplifiers for cable TV customers (Danneels, 2002: 1099). The firm takes advantage of another competency, which are reputation and relations with customers in wire line telecom market, especially cable TV operators (Danneels, 2002: 1099). Hence, a firm needs knowing how to act, knowledge in practice, being able to act with the help of the tools, and special processes such as interactions, information management and evaluation (Quelin, 2000: 477): Knowing includes all of a company's knowledge, culture, professional experience and way of thinking, and knowing how to do is all of the practices and solutions that are meant to solve problems.

Quelin (2000) explains why develop a strategic management of competencies: First one is to enhance the firm's flexibility. Strategic flexibility means that a firm faces a greater range of potential options for action which can then be leveraged to achieve a better fit to its competitive environment (Carayannis, Alexander, 2002: 626). Secondly, they increase the company's 
added value. A competence generates added value from firm's products, processes and organization. Finally, the most important one, a firm's performance is determined by its competence. Therefore, it should be explained how core competence achieves organizational success.

\section{Core Competence: The Road to Organizational Success}

Corporate survival is in the long term dependent on the ability to exploit core competencies (Torkkeli, Tuominen, 2002: 282) because technology, learning and skills are specific to the context of their development and use within the firm, and competencies may have little or no market value to other firms (Lei et al., 1996: 551). Core competencies are irreversible investments that determine the future capabilities and strategic opportunities (Lei et al., 1996: 551). Technology is also key to success since the right technology can offer very effective leverage when a company builds its core competencies (Torkkeli, Tuominen, 2002: 271). Core competence is an entrepreneurial decision-ability to respond to the dynamics of the environment (Banerjee, 2003: 252). Firm-specific capabilities, skills and technologies allow a firm to rapidly catch opportunities in the market, and to constantly watch the changes in the business environment. For example Fujitsu, Honda, Sumitomo and NSK's competence-based missions allow them to obtain achievements and to see opportunities arising in the business (Carr, 1997: 55). Another example is HortReserach Company, a New Zealand scientific research institute: With competition for research and development funding increasing, HortResearch experience shows that core competence strategy process helps senior management to link the portfolio of research projects with changing industry and sector priorities (Clark, Scott, 2000: 496).

Core competencies are therefore currently viewed as the primary means to enable organizations to respond to their environments (Godbout, 2000: 78). HortResearch Company successfully followed the core competence based strategy process throughoutdeveloping industry foresight, generating consensus and committing to an ambitious, future strategic intent, identifying core competencies to create this future (Clark, Scott, 2000: 505).

To reach success, core competencies should not be obsolete or irrelevant; conversely, they should be sustained and improved (Torkkeli, Tuominen, 2002: 275) to develop a unique and effective product/market policy (Godbout, 2000: 78). For example, Fujitsu saw their core competence in terms of complementary technologies, which could be directed into a number of market areas such as multi-media, telecommunications, semiconductors, as well as mainframe and personal computers (Carr, 1997: 54). That example shows that the competitiveness of companies derives from an ability to build the core competences that will result in new business development more speedily than others (Möllersten, Sandberg, 2004: 81). The new business development competence seems to have a marketing orientation, and seems to emphasize a focus on the customer as a source of competitive advantage (Wright et al., 1998: 21). A core competence process for new business development programmes should begin internally interviewing individuals, and then, after interview, the potential core competencies are evaluated with customers, suppliers, and industry experts (Clark, 2000: 116).

New product planning should also include the forecasting the future. Forecasts are used in the development of new products, in the hiring of new personnel, in the addition of capacity in current positions, in the establishment of new operations, and in any other decision requiring an irreversible investment (Makadok, Walker, 2000: 854). The success or failure of an organization will depend on the accuracy of the decision-makers vision of the future (Makadok, Walker, 2000: 855). For small and large organizations, being just one step ahead of the competition is not sufficient unless you can ascertain that you can be continuously ahead (Godbout, 2000: 77).

Building new core competencies helps the firm to penetrate into emerging markets by developing new products that fit to challenges and demands of these markets. They form products in which intra- and interorganizational business strategies, innovative processes, logistics and individual competencies find their expression (Godbout, 2000: 78). Therefore, a new product can satisfy customer quality with the requirement specification (Osterlund, 2001: 161). In addition, product innovation contributes to the competitiveness of the firm through its dynamic and reciprocal relation with the firm's competences (Danneels, 2002: 1095).

Company's major brands will be successfully introduced to market as long as they are manufactured efficiently. Core competence efficiently produces the firm's products and makes good business based upon them (Möllersten, Sandberg, 2004: 84). It is the base for making competitive products (Osterlund, 2001: 160 ) by anticipating customer needs and leveraging resources to provide unique value to customers (Clark, 2000: 116). Textile executives say, their competencies understand the needs of end users of their products, and 
flexible manufacturing through quick changeovers (King, Zeithaml, 2001: 82). Moreover, new products are created by linking competences relating to technologies and customers (Danneels, 2002: 1095). Without knowledge and know-how, organizations become dependent on suppliers and external technology and fail to control the key resources of their sustainability (Godbout, 2000: 78). The only way to earn above-normal economic returns is to forecast the future value of resources to the firm more accurately than competitors (Makadok, Walker, 2000: 855). Core competence development should include customer needs to support them in their business operations. For example, in Sweden, an executive manager of a pulp producer emphasized the importance of giving support to the customer so that the customer's paper machines work properly (Möllersten, Sandberg, 2004: 86). This support will attract new customers toward the company, and hold existing buyers.

Attracting new consumers requires new competencies and organizational renewal to meet the customer demands and to survive in a business environment. An executive manager emphasizes to know customer needs to build a completely new competence in marketing and sales (Möllersten, Sandberg, 2004: 87). New competencies are the knowledge for product innovation that has been recognized as a primary means of corporate renewal that involves the building and expansion of organizational competencies over time (Danneels, 2002: 1095). Therefore, new products in the market will face high success. In other words, new products with a closer fit to firm competences tended to be more successful because competencies involve employee knowledge and skills, technical systems, administrative systems, values and norms (Danneels, 2002: 1096) and because competencies consist of the synergy of intellectual assets such as motivation, employee effort, technological and professional expertise, and methods of collaboration and management processes (Godbout, 2000: 78). A corporate focus on core competencies builds synergy between units and provides the rationale for resource allocation and investment (Clark, 2000: 121).

Core competence is a key to competitive edge because it represents a combination of business specialization and economic utilization of human skills, and hence, is critical success factors of excellent organizations and trend-setting companies (Godbout, 2000: 77). Because a distinctive competence is a differentiated set of skills, complementary assets, and organizational routines which allow a firm to coordinate a set of activities that provides the basis for competitive advantage in a particular market or markets (Williamson, 1999: 1094). In the general hospital industry, the acquisition and deployment of a set of valuable and distinctive competencies will enable a hospital to establish a favorable reputation in the market, thereby, attracting customers (Douglas, Ryman, 2003: 336): That is, the more distinctive hospital's competencies are in a market, the greater the competitive advantage. A firm's core competencies and capabilities profile the current product/market situation and then assess capabilities in terms of future market opportunities (Clark, 2000: 116). For example, for money market mutual funds, the particular competence is the ability to forecast changes in short-term interest rates that has an impact on the economic surplus generated by the fund and its growth (Makadok, Walker, 2000: 853). Moreover, it uses tangible materials such as equipment, machinery, mail list and intangible materials such as manufacturing know-how, understanding of customer needs (Danneels, 2002: 1102).

Much recent research has shifted from focusing on tangible assets as a source of competitive advantage to include intangible assets such as competence and experience (Pehrsson, 2004: 272). This utilization of resources means improvement in organizational learning, i.e., learning by doing. Learning new competence makes a firm competitive in the future (Osterlund, 2001: 159) because the combination of firm-specific assets or resources enables a firm to accomplish a given task (Danneels, 2002: 1102). By doing this, core competencies give a company power to control the future shape of markets and industries, and to determine the destiny of organizations (Clark, 2000: 115). For instance, TELECOM's core competency is RF amplifiers, and its wireless products are closely aligned with its technological competences that gives the firm the ability to design and manufacture a physical product with certain features that customer wants (Danneels, 2002: 1103). A company can perform high growth rate by leveraging core competence. Therefore, firm strategies should be based on core competencies which are unique, knowledge-based, organization-wide capabilities (Clark, Scott, 2000: 496). Hence, managers must think of how the competence might be applied in new product areas (Danneels, 2002: 1108). For example, firms such as Eastman Kodak, IBM and Motorola apply their core competencies to develop new successful products because their competencies give them this ability. Eastman Kodak's core competence might be considered imaging; IBM's might be considered integrated data processing and service, and Motorola's untethered communication (Williamson, 1999:1093).

Strategy making focuses on the firm's heterogeneous resources, capabilities and competencies as those pro- 
vide a more stable basis for competitive positioning in a turbulent environment (Clark, 2000: 116). Because competencies produce high-quality products that add value to consumers. According to Douglas and Ryman study (2003), the value of a hospital's strategic competencies is positively related to hospital financial performance. Pehrsson (2004) also found the same result that high strategy competence is generally associated with high performance of the entrant business. The way in which competencies are mustered will be a primary factor in determining the degree of difference between average and superior performance (Godbout, 2000: 83). Because it provides a new way of thinking about future priorities and positioning, which are the factors critical for successful core competence strategy implementation (Clarl, Scott, 2000: 507). In the contemporary management literature, there is prevailing belief that organizations which learn to work systematically with their core competencies achieve considerable strategic power (Godbout, 2000: 78). It also develops an organization's capability in building shared vision, personal mastery, and system thinking that is to understand wholes, and to learn how the actions shape the strategy (Osterlund, 2001: 165). This requires organizational changes. The most successful changes and turnarounds in the Western industrial world are cases where organizations have concentrated on the core competencies of the organization and the quality of competencies of their employees (Godbout, 2000: 76). At the organizational level, core competence based strategy making will translate into changes- new products, new processes, new skills and new people (Clark, 2000: 123). For instance, HortResearch Company culminates the transformation of their organization from a bureaucratic Government department to a commercially successful science business by the process of developing a new strategy based on core competencies (Clark, Scott, 2000: 496).

The core competence approach to strategy making is only one of many contributions within emerging resource based view of the firm, and arrived at a time when executives in large corporates were aware that many of the traditional approaches were inadequate, and it offered a compelling rationale for corporate strategy decisions, resource allocation and competition (Clark, 2000: 115). Moreover, a core competence helps an organization achieve its chosen competitive advantage by providing customer value, competitor differentiation, and extendibility to markets (Franklin, 1997: 373). Therefore, the acquisition and development of the right core competences to create future is clearly a strategic issue (Franklin, 1997: 374) because shaping future deals with positioning the firm in the industry (Douglas, Ryman, 2003: 333). Therefore, forecast the future is a specific competence that a firm should have (Makadok, Walker, 2000: 854). HortResearch Institute is successful in implementation of core competence strategy making by managing the three core elements of their business: Anticipating future needs, managing integrated research teams, and delivering innovative and effective solutions (Clark, Scott, 2000: 501). Makadok and Walker's study (2000) shows that superior forecasting ability generates an economic surplus, and that the stronger a firm's forecasting competence, the larger the firm will subsequently grow. Two key components of firm success are firm core competencies and industry structure; thus, a firm must develop competencies that allow it to successfully position itself within its industry (Douglas, Ryman, 2003: 333).

Any company that aims to obtain competitive edge should build causal ambiguity to save their core competencies. Executives emphasize that if a competitor could copy their information systems, which is their core competence, they would lose much of their competitive advantage (King, Zeithaml, 2001: 82). Causal ambiguity, which is ambiguity about the link between firm resources and sustained competitive advantage, protects resources from competitive imitation although socially complex resources such as a good reputation and trust are time-consuming and expensive to imitate (King, Zeithaml, 2001: 76). Causal ambiguity among competitors protects the firm because competitors cannot imitate valuable competencies if they do not understand the relationship between these resources and competitive advantage (King, Zeithaml, 2001: 76).

\section{Discussions and Conclusion}

This study is about investigating the impact of core competence of a firm on organizational success. The study aims to clear two important questions: What are we really good at? What distinguishes us in the marketplace, adds value to our products and services, and gives us a competitive advantage? (McNerney, 1995: 3 ). The reason to focus on those questions is because the translation for "core competency" is market dominance (McManus, 1995: 17). It is a market dominance since a core competency is simply something a company does better than any of its competitor (Vadhanasiripong, 2000: 7).

Core competence is a firm-specific organizational signature that introduces winning products to market that provides a firm with competitive advantage. The corporate signature emerges from organizational knowledge, expertise, experience, systems, technology, skills, capabilities, and resources. Those are the fac- 
tors that differentiate the firm in the market, and that are difficult to imitate by rivals, and finally, that develop new assets and specializations within the organization in order to catch market opportunities.

A firm obtains organizational success with the help of core competence that contains distinct qualities above, and that provides a company with rational resource usage to produce successful products. New product development and new market penetration based on core competence strategy enable the firm to have new growth alternatives. Because core competence involves technologies and social learning unique to the firm. For example, competencies such as technical know-how, quality improvement instruments, knowledge about consumer requirements, and firm reputation make the firm build winning strategies. That is to say, leveraging resources enhances company's competitive superiority. Moreover, core competence improves the quality of in-house operations by integrating technology, skills, experience, and know-how.

Distinctive core competencies differentiate the firm from their competitors in how to use and leverage their resources to beat the competition. They also provide a management for dismissing organizational weaknesses and external threats. Each corporation has various resources, but companies differ in how they leverage them (Torkkeli, Tuominen, 2002: 274). Capabilities, which are a set of process in the organization, also make difference in organizational operations and manufacturing to increase product quality. Duysters and Hagedoorn (2000) believe that technical core capabilities generate performance differentials. Therefore, capabilities should have importance in developing core competence strategy because both capabilities and core competencies manufacture high-quality products, watch customer wants, and develop new products to put into markets. The importance comes from the ideas that capabilities refer to the corporation's ability to exploit organizational resources (Torkkeli, Tuominen, 2002: 274). This is why upperlevel managers is evaluated by managing and exploiting core competence of their organization.

To increase organizational efficiency depends mainly on executing core competence strategy. Because a competence uses specialization, knowledge, skills, and experiences to effectively run resources. These resources build organizational value on end products consumed by customers. Thus, plenty of firms search effective ways for managing competencies to take the most advantageous, and to decrease uncertainty. In a sense, the real sources of competitive advantage are the management's ability to consolidate corporate wide technologies and production skills into competencies that empower the firm to adapt quickly to changing opportunities (Prahalad, Hamel, 1990: 81).

Firms develop core competence to support their current products, and so, to increase their competitiveness. This is why, in addition to capabilities, activities; technology etc., effective management of developing competencies should include the experiences, skills and aptitudes of human resources that use knowledge resources to achieve organizational goals. Because human resources of firm uses knowledge resources to reach organizational goals. Therefore, employees ought to join to efforts of developing core competence. These efforts are keys to competitive success because competencies increase the organizational flexibility to effectively respond to the business environment.

Core competence encourages entrepreneurial activities in the organization to respond rapid changes in the environment. That will result in firm survival in the long run. To stay in the business depends more on exploiting competencies because it identifies the future priorities, capabilities, and opportunities. The success or failure of an organization will depend on the accuracy of the decision-makers vision of the future (Makadok, Walker, 2000: 855). In addition, core competence improves synergy among organizational departments by collaborating resources, experiences, knowledge and skills. It is critical success factors of excellent organizations and trend-setting companies, and represents a combination of business specialization and economic utilization of human skills (Godbout, 2000: 77).

Competencies show a firm its present situation in the market, and help a firm to monitor and acquire needed capabilities to catch market opportunities. The combination of firm-specific assets, resources, and capabilities enable a management to accomplish this task (Dannels, 2002: 1102).

Core competence has an ability to give a company power to control the future shape of markets and industries, and to determine the destiny of organizations (Clark, 2000: 115). Core competence provides this power to firm with new product development. New products, which are built on competencies, are successfully introduced into the marketplace because competencies involve specific and distinctive organizational knowledge, skills, and values. Therefore, in development of competence-based new product, top management should call attention to customer demands to satisfy them in their business operations. This will lead to attracting new buyers for the compa- 
ny. An executive manager emphasizes to know customer needs to build a completely new competencies (Möllersten, Sandberg, 2004: 87), and new products.

In conclusion, core competence determines the degree of difference between average and superior performance (Godbout, 2000: 83). It helps a management to shape firm's market position by forecasting future. Superior forecasting ability generates an economic surplus, and the stronger a firm's forecasting competence, the larger the firm will subsequently grow (Makadok, Walker, 2000: 855). Core competence means value for consumer, differentiation of a firm, and entrance to new markets; therefore, organizational strategies should be based and built on core competencies to be winner and successful in business life. The most successful changes and turnaround in the Western industrial world are cases where organizations have concentrated on the core competences of the organizations and the quality of competences of their employees (Godbout, 2000: 76).

\section{REFERENCES}

Banerjee, P., (2003), Resource Dependence and Core Competence: Insights from Indian Software Firms, Technovation, 23, pp.251-263.

Carayannis, E.G. and Alexander, Jeff., (2002), Is Technological Learning a Firm Core Competence, When, How andWhy? A Longitudinal, MultiIndustry Study of Firm Technological Learning and Market Performance, Technovation, 22, pp.625-643.

Carmeli, A. And Tishler, Asher, (2004), Resources, Capabilities, and the Performance of Industrial Firms: A Multivariate Analysis, Managerial and Decision Economics, 25, pp.299-315.

Carr, Chris, (1997), Competency-led Strategies Based on International Collaboration: Four Case Studies of Anglo-Japanese Cooperation, Knowledge and Process Management, 4, pp.49-62.

Clark, Delwyn N., (2000), Implementation Issues in Core Competence Strategy Making, Strategic Change, 9, pp.115-127.

Clark, D.N. and Scott, Dorian N., (2000), Core Competence Strategy Making and Scientific Research: The Case of HortResearch, New Zealand, Strategic Change, 9, 495-507.

Dannels, Erwin, (2002), The Dynamics of Product Innovation and Firm Competences, Strategic Management Journal, 23, pp.1095-1121.

Davis, Tim R.V., (1999), Different Service Firms, Different Core Competencies, Business Horizons, September-October, pp.23-33.

Douglas, T.J. and Ryman, Joel A., (2003), Understanding Competitive Advantage in The General Hospital Industry: Evaluating Strategic Competencies, Strategic Management Journal, 24, pp.333-347.

Duysters, G. And Hagedoorn, John, (2000), Core Competences and Company Performance in the WorldWide Computer Industry, Journal of High Technology Management Research, Spring, 1, pp.75-92.

Franklin, Peter, (1997), Competitive Advantage and Core Competences, Strategic Change, 6, pp.371-375.

Gallon, M.R. and Stillman, Harold M., (1995), Putting Core Competency Thinking into Practice, 
Research Technology Management, 38, pp.20-32.

Godbout, Alain J., (2000), Managing Core

Competencies: The Impact of Knowledge

Management on Human Resources Practices in Leading-edge Organizations, Knowledge and Process Management, 7, pp.76-86.

Hamel, G. And Prahalad C.K., (1994), Competing for the Future, Harvard Business Review, July-August, pp.122-128.

Harvey, M.G. and Buckley, Ronald M., (1997), Managing Inpatriates: Building a Global Core Competency, Journal of World Business, 32, pp.3557.

Higgins, James M., (1996), Achieving the Core Competence-It's as easy as $1,2,3, \ldots .47,48,49$, Business Horizons, March-April, pp.27-32.

King, A.W. and Zeithaml, Carl P., (2001), Competencies and Firm Performance: Examining the Causal Ambiguity Paradox, Strategic Management Journal, 22, pp.75-99.

Lei, D., Hitt, M.A. and Bettis, Richard, (1996), Dynamic Core Competences through Meta-Learning and Strategic Context, Journal of Management, 22, pp.549-569.

Makadok, R. and Walker, Gordon, (2000), Identfying a Distinctive Competence: Forecasting Ability in the Money Fund Industry, Strategic Management Journal, 21, pp.853-864.

McManus, John, (1995), Core Competency, Market Dominance, Means Get Out Front, or Get Lost, Brandweek, 36, pp.16-19.

McNerney, Donald J., (1995), Designer Downsizing: Accent on Core Competencies, HR Focus, 72, pp.1-7.

Mollersten, K. and Sandberg, Peter, (2004),

Collaborative Energy Partnerships in Relation to

Development of Core Business Focus and Competence-A Study of Swedish Pulp and Paper Companies and Energy Service Companies, Business Strategy and the Environment, 13, pp.78-95.

Osterlund, Jan, (2001), The Forgotten Revenue of Product Development: Learning New Competence, Systems Research and Behavioral Science, 18, pp.159-170.

Pehrsson, Anders, (2004), Strategy Competence: A study of Successful Business Establishments, Strategic Change, 13, pp.271-282.

Phelan, Mark, (1998), Fiat Redefines Core Competency, Automotive Industries, 178, pp.171174.

Prahalad, C.K. and Hamel, Gary, (1990), The Core Competence of the Corporation, Harvard Business Review, May-June, pp.79-91.

Quelin, Bertrand, (2000), Core Competencies, R\&D Management and Partnerships, European Management Journal, 18, pp.476-487.

Stalk, G., Evans, P. And Shulman, Lawrence E., (1992), Competing on Capabilities: The New Rules of Corporate Strategy, Harvard Business Review, March-April, pp.57-69.

Torkkeli, M. And Tuominen, Markku, (2002), The Contribution of Technology Selection to Core Competencies, International Journal of Production Economics, 77, pp.271-284.

Vadhanasiripong, C., (2000), Be Careful not to Outsource your Core Competency, Business Week, 3702, pp. 6-7.

Williamson, Oliver E., (1999), Strategy Research: Governance and Competence Perspectives, Strategic Management Journal, 20, pp.1087-1108.

Wright, P.M., McMahan, G.C., McCormick, B. And Sherman, Scott W., (1998), Strategy, Core Competence, and HR Involvement as Determinants of HR Effectiveness and Refinery Performance, Human Resource Management, 1998, 37, pp.17-29. 